\title{
The Use of the VCT Model in Civic Education to Build the Moral Awareness of Students in the Global Era
}

\author{
Shelvy Oktavia $\mathrm{S}^{1},{ }^{*}$ Aim Abdulkarim ${ }^{2}$
}

1,2, Universitas Pendidikan Indonesia
* Corresponding author. Email: shelvyoktavias@upi.edu

\begin{abstract}
This study aims to provide an overview of the use of the VCT (Value Clarification Technique) model in Civic Education to foster students' moral awareness. In the current global era, there are many moral crises experienced by students caused by a lack of moral awareness. The design used in this study is a qualitative approach. Data collection techniques are carried out through observation, documentation studies, literature studies, research results are carried out through the stages of analysis and verification or concluding to obtain conclusions. Based on the results of the study, it can be concluded that: Morals are an inseparable part of human life, morals are characteristics that show patterns of human behavior in carrying out their lives. Good morals show that a person has good behavior or behavior patterns, and vice versa. In this era of globalization, of course, moral issues get special attention, especially among teenagers. So there is a need for moral awareness in learners to fortify themselves. In an increasingly global era, a learning model is needed to build moral awareness in learners, which can be done through the learning of citizenship education, namely the use of the VCT (Value Clarification Technique) model applied by teachers in the classroom. The VCT model is an innovative learning model that can be applied in Civics learning in fostering the moral awareness of students in the global era. Growing awareness in students that morals are a very important part of carrying out life as good citizens. The global era cannot be avoided, but its development must be followed by continuing to apply moral values as well as strengthening and fostering moral awareness within oneself.
\end{abstract}

Keywords: Citizenship Education, Globalization, Moral Awareness, VCT.

\section{INTRODUCTION}

At this time advances in technology, information and communication are unavoidable, their rapid development has become an inseparable part of human life. This is marked by the widespread use of gadgets or gadgets and the internet in people's lives, especially among teenagers, which have become a necessity of daily life. The development of technology, information, and communication not only has an impact on human life in terms of economy, politics, and industry but also has an impact on the development of education. The development of the industrial era is known as the use of technology, communication, and information in all aspects, including education in the learning process [1]

The statement by Schunk the existence of technology provides convenience in the teaching process, wherewith technology students can experience simulations that are not found in ordinary classes, make learning more interesting, then can carry out the learning process indirectly, and can interact with others expert teaching system [2].
So that it can be seen that the existence of technology affects the development of education, namely helping and facilitating the process of implementing learning, which used to be done in a monotonous way, now it can be done innovatively with the help of technology, and can help educators provide real examples to students when the learning process is carried out the implementation of learning.

In the global era with technological advances that can access everything, without any limitations of time and place. This is as stated by Mothohar that in the current era of globalization, the educational environment for adolescents is no longer monotonous and limited in the school environment or educational institutions. Children may be in a school environment, but now they have access to connect, see directly, and can be involved in other lives in other worlds with technology and information media. [3].

This also hurts students with the development of technology. One of the negative impacts is the occurrence of moral degradation or decline. The low 
morale of the nation is one of the impacts of globalization which is very disturbing, almost all of the younger generation are affected by globalization such as addiction to gadgets and social media. Addiction to this object is one of the effects of globalization that erodes the morale of the Indonesian nation [4].

Like the case that went viral in Indonesia in 2020. There are several youths in Bandung named Ferdian Paleka along with his colleagues, doing a PRANK KASIH MAKANAN KE BANCI BCL, which was uploaded to a youtube account on Sunday, May 3, 2020. In the video, which took place on Jalan Ibrahim Adjie, Bandung, Ferdian Paleka was seen distributing groceries to transgender women, which turned out to be trash and rocks [5]. From this case, it is clear that there is a moral decline due to the negative impact of technology. They post and share the video, which becomes public consumption, is a negative debate that should not be imitated.

It should be, as expected that the presence of these technological advances can be used and utilized as best as possible. simplify and streamline all affairs, which becomes more effective and efficient. But in reality, this technological advancement also has a negative impact, especially among teenagers, who in general are not stable themselves, easily influenced by external conditions.

As a solution to overcome these problems, namely through civic education. Civic education has the aim of forming good citizens [6]. Of course, a good citizen has good moral values based on Pancasila. Civic education has three very important components, namely Civic Knowledge, Civic Skill, and Civic Disposition [7].

In civic education to instill moral awareness, it is necessary to apply an innovative learning model that is by the development of globalization, namely the VCT learning model. VCT is a learning model with value education techniques where students are trained to find, select, analyze, assist students in finding and deciding to Take their attitude about the values of life [8].

With the application of the VCT model in civic education, it is hoped that the material presented by the teacher can be well received by students. learning becomes more interesting. Furthermore, students become more active and can increase moral awareness in behaving in the life of society, nation, and state based on the values of Pancasila.

\section{THEORETICAL REVIEW}

\subsection{Civic Education}

Civic education is a subject given to students, to raise awareness of their rights and virtues as citizens, and to form good behavior based on the 1945 Constitution and Pancasila. In addition, Citizenship Education is a subject of moral education, moral education is an effort to guide the personality development of students based on Pancasila [9]. So that Citizenship Education has an important role in fostering children's morals how they should behave as citizens who uphold the basic integrity of Pancasila. According to Wadu, Darma, \& Ladamay, (2019) stating that civic education is a lesson that ultimately produces moral Indonesian citizens [10]. In addition, civic education is designed to provide skills and knowledge to citizens as a provision in carrying out social life, as well as knowing their rights and obligations as good citizens. [11]

The purpose of Citizenship Education delivered by Mahendra (2018) states that civic education in its aim is how to be able to produce good and responsible citizens' traits and behaviors as well as benefit the community, nation, and state in carrying out a life [12]. Then the purpose of citizenship education in detail is basically to form citizens who are ready to face challenges in the era of globalization [6].

\subsection{Globalization}

The existence of technology is marked by technological advances, such as the emergence of robotics, artificial intelligence, and others [13]. Globalization can affect a person through various paths, both positive and negative impacts. A very deep impact is felt by the community, namely advances in communication technology, making it easier for someone to communicate with each other in all parts of the world [14]. This understanding is supported by the opinion which states that globalization can affect all aspects of human experience which cannot be avoided [15].

So it can be seen that globalization stands for 'change' that occurs in many unexpected ways and many different domains [16]. In addition, it includes such things as global communication systems and various aspects of information, the latter of which emphasizes the dissemination of cultural values [17].

\subsection{Moral Awareness}

Moral implies the integrity of the human person, namely the dignity and worth of a person. Moral implies the integrity of the human person, namely the dignity and worth of a person. The degree of a human's personality is largely determined by his morals. The moral is the most important part of human life, which shows its identity as a living being. The moral is the most important part of human life, which shows its identity as a living being. morality is an inseparable part of social life, as a guide that must be possessed by all humans to achieve recognized social values so that humans can live according to the rules that are set simultaneously. [18].

Moral awareness is human awareness that accompanies awareness of norms in society and the moral nature of a norm is a trait that is realized when used. Humans are born with moral potential. And the moral potential grows and develops in social relations with fellow humans, nature, and society. Finally, moral 
awareness is formed through the stages of moral development [19]. Moral awareness needs to be instilled early on in students so that later they apply good values, morals, and norms by the rules that apply both in the life of the nation and state.

The purpose and function of morals are to ensure the upholding of one's dignity and humanity, motivate goodness and virtue in every human attitude and action, humans do good and benevolence based on an awareness of obligations that are based on morals, and morals provide a basis for patience, to endure against all odds instinctive drives and desires (lusts), providing endurance in delaying or rejecting inferior impulses that threaten the dignity of the human person [18].

\subsection{Value Clarification Technicque (VCT)}

VCT is a learning model regarding the clarification of values contained in students VCT is a model that helps to increase student's awareness of the values that exist within themselves, which will then be integrated with values outside themselves to be planted [20]. According to Taniredja, et al stated that the VCT model has several principles, namely:

2.4.1 First, there is growth, cultivation, and changes in attitudes and values caused by several factors, such as self factors, family environment, school environment, and the environment in society.

2.4.2 Second, pay attention to the level of moral development, because values, morals and norms are influenced by development. Then the level of development is also influenced by the level of age and social environment

2.4.3 Third, there is a skill to clarify values/attitudes rationally and clearly.

2.4.4 Fourth, there is openness in changing values [21]

In addition to the principles, in line with Djahiri, the application of the VCT model is intended to provide an assessment of something, assessment is done clearly and responsibly, the ability to decide matters clearly and objectively, and be able to implement values that apply in life [22].

Furthermore, the purpose of VCT is to provide direction to students in assessing, accepting, and making decisions regarding problems related to everyday life. So that students can accept the values they believe are good and can behave by these values without any doubt [23].

\section{RESEARCH METHOD}

The use of a qualitative approach aims can obtain information and factual data naturally and explore indepth. The use of qualitative descriptive aims to produce data information in the form of the meaning of a word expressed in writing or orally which is conveyed directly by the object under study [24]. Data collection techniques are carried out through observation, documentation studies, literature studies, then the research results are carried out through the stages of analysis and verification or concluding.

The participants in this study were Citizenship Education Teachers and Class XII students.This research will be conducted at SMAN 1 Tulang Bawang Tengah. Located at Jalan Dahlia No. 02, Panaragan Jaya, Tulang Bawang Tengah, Tulang Bawang Barat Regency, Lampung.

\section{RESULTS AND DISCUSSION}

In this era of globalization which is all-sophisticated, we find a lot both in the surrounding environment and on social media regarding the crisis of values and morals. The more sophisticated the technology, the more erosion and fading of Pancasila values in everyday life. For example in the surrounding environment, long before getting to know technology when a younger person passes in front of an older person, he will bow politely as a sign that he respects those who are older than himself. But in reality, at this time the sight was rarely seen. In addition, there are lots of reports in the media about cases of students fighting their teachers and even yelling at their teachers. Actions like this show an act of deviation from the values of Pancasila and show that there has been a moral crisis.

According to Bahri states that many factors are the cause of the moral crisis, one of the factors that have the greatest influence is the information media ranging from television, internet media, and so on. Internet media has a tremendous impact on teenagers today, both positive and negative impacts [25]. To overcome this, students are provided with education or learning in which some values can shape the child's personality for the better. and live their lives by the values of Pancasila. One of them is Citizenship Education.

However, from the results of observations made, it shows that students are less active in learning Civics, one of the reasons is due to the monotonous learning process. When learning takes place, students tend to feel bored with the learning material presented. This is because the teacher only uses the lecture method. To overcome this solution, the VCT model is used in the learning process. However, after the teacher used the VCT learning model, the students became enthusiastic about participating in the lesson. In addition, the application of the VCT learning model in Citizenship Education encourages students to grow the importance of moral awareness in themselves. Then through this VCT model, students will also have the competence of good attitudes, knowledge, and skills.

As it is known that Citizenship education has a goal, namely to form good citizens [6]. Of course, good citizens are citizens who have good attitudes, patterns of behavior and are moral. To achieve this goal, citizens have been instilled with moral awareness from an early age. through the VCT model in Civic Education 
learning. Especially among the teenagers who will later become their provisions, when they have plunged directly into the life of the nation and country. In learning Citizenship Education using the VCT model, students will learn to find and apply good values for them.

Based on the findings in this study, it can be said that the use of the VCT model in learning can foster students' enthusiasm for learning, students can solve problems creatively, can work well together, respect differences of opinion and students realize the importance of having awareness. morals, as the next generation of the nation, as well as fostering the moral knowledge of students. Moral knowledge has value in terms of the first knowledge in the dominant "right and wrong" to produce moral enlightenment, secondly, humans are moral humans who consciously understand "right and wrong" [26].

Then during the learning process through the VCT model, students are orderly, obeying applicable regulations, mutual respect for fellow friends and teachers, mutual respect for differences of opinion. These values will become their habituation in life. In addition, civic education based on the VCT learning model is expected to prepare students to become citizens who have a strong commitment to live a life based on Pancasila values in the global era. Because basically, the VCT model does not only emphasize the cognitive aspect but also the affective and psychomotor aspects whose learning is centered on the learner.

This is supported by research conducted in 2020 by M. Lifa, et al. that the results show that the application of the VCT (Value Clarification Technique) model in Civic Education learning has a positive impact on the development and improvement of moral values which include religious attitudes and social attitudes [27]. Then the results of this study were also strengthened and by the theory presented by Z. R. Hakim, et al., stated that the VCT model aims to provide direction for students to determine and accept good values to carry out their lives [23].

So that citizenship education in the application the VCT model to make learners become active citizens understand and comply with all norms and provisions that apply in community life, by having moral awareness in behaving and cooperating between citizens.

\section{CONCLUSION}

Based on these findings, it can be concluded that in an increasingly global era, a learning model is needed to foster moral awareness in students. One of the learning models that are considered capable of fostering the moral awareness of students in the global era is the VCT learning model. The VCT model is an innovative learning model that can be applied in Civics learning.
Teachers can apply this model, so that Civics learning is no longer boring or monotonous, but becomes more interesting. As well as the material delivered by the teacher can be accepted in the end it will foster awareness in students that morals are a very important part in carrying out life as citizens, especially in this era of globalization moral values must be embedded.

\section{ACKNOWLEDGMENTS}

We thank the Indonesian University of Education, Bandung, Manado State University, Manado, and The Third Annual Civic Education Conference on "Civic Education in Pandemic Covid-19: Challenges and Responses" for support.

\section{REFERENCES}

[1] E. Endangsari, \& Sapriya, "The Application of Blended Learning Through Edmodo and Kahoot on Civic Education to Form 21st Century Skills in Secondary School", Atlantis Press. hal, 114. Maret 2020. https://doi.org/10.2991/assehr.k.200320.022

[2] D. H.Schunk, "Learning Theoris An Educational Perspective Yogyakarta: Pustaka Pelajar. hal. 449. 2012.

[3] S. Muthohar, "Antisipasi Degradasi Moral di Era Global", Jurnal Pendidikan Islam: vol, 7. no, 2. 2013. DOI :10.21580/nw.2013.7.2.565

[4] N. Y. P. Pratama. \& D. A. Dewi.. "Implementasi Nilai-Nilai Pancasila dalam Membentuk Moral Bangsa vang Terkikis Akibat Benturan Globalisasi". .Jurnal Pendidikan Tambusa: vol, 5. no, 1. hal, 963. 2021. ID: https://orcid.org/0000$\underline{0001-8590-9341}$

[5] Kumpara.com. Kronologi Kasus YouTuber Ferdian Paleka, Bikin Prank hingga Diciduk Polisi. https://kumparan.com/kumparannews/kronologikasus-youtuber-ferdian-paleka-bikin-prank-hinggadiciduk-polisi-1tNEDx0Pzaq/full

[6] A. A. Wahab dan Sapriya, "Teori dan Landasan Pendidikan Kewarganegaraa". Bandung: Alfabeta CV. hal. 311. 2011

[7] D. Budimasnyah, dan U. Winataputra, "Civic Education, Konteks, Landasan Bahan Ajar dan Kultur Kelas". Bandung: Pendidikan Kewarganegaraan Sekolah Pascasarjana. 2017

[8] F. Haris, "Penerapan Model Pembelajaran VCT (Value Clarification Technique) Untuk Meningkatkan Kesadaran Nilai Menghargai Jasa Pahlawan pada Siswa Sekolah Dasar". Jurnal Penelitian Pendidikan Guru Sekolah Dasar: vol, 1. no, 2. hal, 2. 2013

[9] M. Nasrullah., Budiono, dan A. Tinus, "Implementasi" Nilai-Nilai Demokrasi dalam Pembelajaran Pendidikan Pancasila dan Kewarganegaraan di MAN Langke Rembong Ruteng Nusa Tenggara Timur". Jurnal Civic Hukum: vol, 3. no, 2, hal, 198. 2018. DOI: $\underline{10.22219 / j \mathrm{ch} . v 3 \mathrm{i} 2.8661}$

[10] L. B. Wadu., I.P. Darma, dan I. Ladamay, "Pengintegrasian Nilai Moral Melalui Pendidikan Pancasila dan Kewarganegaraan di SMP”. Jurnal 
Inspirasi Pendidikan: vol, 9. no, 1. hal, 68. 2019. DOI: $10.21067 /$ jip.v9i1.3067

[11] Baeihaqi, "Civic Education Learning Based on Law-Related Education Approach in Developing Student's Law Awareness", Atlantis Press. hal, 45. Maret 2020.2 DOI: https://doi.org/10.2991/assehr.k.200320.009

[12] P. R A. Mahendra, "Civic Culture Ngayah dalam Pembelajaran PPKn". Jurnal PPKn: vol, 6. no, 1. hal, 1241. 2018

[13] A. Madhok. "Globalization, de-globalization, and re-globalization: Some historical context and the impact of the COVID pandemic". Article reuse guidelines: sagepub.com/journals-permissions: vol, 24. no, 3, hal, 201. April 2021. DOI: $\underline{10.1177 / 23409444211008904}$

[14] V. J. Jani, N. A. Joshi and D. J. Mehta. "Globalization and health: An empirical investigation". Article reuse guidelines: sagepub.com/journals-permissions: vol, 19. no, 3. Febuari 2019. DOI: $10.1177 / 14680181198274$

[15] R. Rubira, dan G. Gil-Egui. "Wikipedia as a space for discursive constructions of globalization". Article reuse guidelines: sagepub.com/journalspermissions: vol, 81. no, 1. hal, 11. Oktober 2017. DOI: $10.1177 / 1748048517736415$

[16] L. Pauwels. "Exposing globalization: Visual approaches to researching global interconnectivity in the urban everyday". Article reuse guidelines: sagepub.com/journals-permissions: vol, 34. no, 3, hal, 4. Maret 2019. DOI: $10.1177 / 026858091983515$

[17] C. Pankratz. "A Multitypological Approach to the Relationship Between Welfare States and Globalization". journals.sagepub.com/home/sgo: vol, 7. no, 1, hal, 4. February 2017 DOI: $10.1177 / 2158244017692381$

[18] M. Firwan, "Nilai Moral dalam Novel Sang Pencerah Karya Akmal Nasrey Basral". Jurnal Bahasa dan Sastra: vol, 2. no, 2. hal, 52. 2017

[19] E. Pujiati, "Hubungan Antara Prestasi Belajar PKn dengan Tingkat Kesadaran Moral Siswa Kelas VII Di MTS Sunan Kalijogo Kabupaten Malang", Jurnal Ilmiah Fakutas Keguruan dan Ilmu Pendidikan Universitas Wisnuwadhana: vol, 19. no, 1. Hal, 29. 2019

[20] S. Adisusilo, Pembelajaran Nilai-Karakter Konstruktivisme dan VCT sebaga Inovasi Pendekatan Pembelajaran Afektif. Jakarta: Rajawali Pers. hal, 149. 2013

[21] T. Taniredja., E. M. Faridli, dan S. Harmianto, "Model-Model Pembelajaran Inovatif dan Efektif." Bandung: Alfabeta CV. hal, 89. 2017
[22] V. Fitriyani dan D. Sundawa, "Penerapan Model Vct (Value Clarification Technique) Dengan Menggunakan Media Cerita Daerah dalam Pembelajaran Pendidikan Kewarganegaraan Untuk Meningkatkan Karakter Peserta Didik". Jurnal Pendidikan Ilmu Sosial. vol, 25. no, 1. Hal 44. 2016

DOI: https://doi.org/10.17509/jpis.v25i1.3669

[23] Z. R. Hakim., M. Taufik, dan M. Atharoh, "Penerapan Model Pembelajaran Vct (Value Clarification Technique) Terhadap Kemampuan Pemecahan Masalah Siswa Pada Mata Pelajaran IPS di Sekolah Dasar Negeri Cimanis 2 Sobang Pandeglang". Jurnal Pendidikan \& Pengajaran Guru Sekolah Dasar: vol, 1. no, 1. hal, 32. 2018. DOI: 10.33751/jppguseda.v1i01.869

[24] M. Mulyadi,. "Penelitian Kuantitatif dan Kualitatif serta Pemikiran Dasar Menggabungkannya". Jurnal Studi Komunikasi dan Media: vol, 15. no, 1. hal, 132. 2011. DOI: $10.31445 /$ jskm.2011.150106

[25] S. Bahri, "Implementasi Pendidikan Karakter Dalam Mengatasi Krisis Moral Di Sekolah". Ta'allum: Jurnal Pendidikan Agama Islam: vol, 3. no, 1. 2015.

[26] D. Gao, \& D. Wang, "Rethinking "Basic Issues" in Moral Education". ECNU Review of Education, Sage journal, pp. 1-20. Oktober 2020. DOI: https://doi.org/10.1177/2096531120950322

[27] M. Lifa, Sulistyarini, dan J. A. Dewantara, "Analisis Penerapan Model Pembelajaran Value Clarification Techniqiue (VCT) untuk Meningkatkan Nilai Moral Peserta Didik". Journal of Elementary Education: vol, 4. no, 4. Hal. 955968.

DOI: https://doi.org/10.31004/basicedu.v4i4.480 